\title{
Drivers for the writing of a sermon about reconciliation
}

C J A Vos

(University of Pretoria)

\section{ABSTRACT \\ Drivers for the writing of a sermon about reconciliation}

This article focuses on the energy that must fill the homiletic space, in order for an effective sermon about reconciliation, to be created. Of concern is the liturgical situation in which, sermons about reconciliation take place - the homiletic process through which a homiletic theory is established, the sermon as a work of art and its structure. All these liturgical and homiletic motivators release energy, which enables preaching about reconciliation to take place in a way that moves the listener. Reconciliation means to overcome the divide between the rich and the poor and looking at other people the other person through different eyes.

\section{ORIENTATION}

Certain energy can only be released in a certain space. When too much energy is released, the optimal function of this energy is restricted. The same applies to the process of creating a sermon. This article focuses on the energy that must fill the homiletic space, in order for an effective sermon about reconciliation, to be created.

This contribution focuses on the liturgical situation in which, sermons about reconciliation take place - the homiletic process through which a homiletic theory is established, the sermon as a work of art and its structure. All these liturgical and homiletic motivators release energy, which enables preaching about reconciliation to take place in a way that moves the listener.

In the Old and the New Testaments, reconciliation has a rich semantic field. This contribution focuses on two semantic fields found in the New Testament. In certain parts of the Pauline literature, reconciliation is demonstrated as a social rift that has been repaired. This reparation results in, amongst others, peace and happiness. In the general letters, reconciliation is demonstrated by the bridge, which is built between the rich and the poor. Reconciliation means to overcome 
the divide between the rich and the poor. It means looking at the other person through different eyes.

\section{THE LITURGICAL SITUATION}

Sermons about reconciliation are not merely sermons, but sermons in a liturgical context. Therefore, the homiletician must be sensitive to the liturgical context. This means that he/she must have knowledge of, and insight into, the liturgical tradition, the power of the liturgy and how it functions. The liturgical situation has both a hermeneutic and a communicative side to it and the homiletician also has a liturgical responsibility. To fulfill this responsibility, he/she and those attending the divine service must learn to discover and experience the meaning of each liturgical action. The liturgy is more than the sermon - it also has a communicative function and impact. All the liturgical acts have a significant religious function, while there is an art to celebrating salvation truthfully.

\section{THE SERMON AS A WORK OF ART}

The homiletician's ability to gauge the exegetical, hermeneutic and socio-cultural richness of texts means little, if these texts are not used within the framework of a sermon, which communicates effectively to the listeners and moves them. Sermons are the wings upon which messages are carried to the listeners. Following the hermeneuticcommunicative approach, the challenge for the homiletician is to craft a sermon with care and make it a work of art. 'Not just cutting the carrot took attention, but picking the knife up, putting the knife down, wiping the knife, cleaning the knife, sharpening the knife, storing the knife' (Ed Espe Brown). This is the posture of the sermon. The sermon must be fleshed out, so that it can touch people. The words of Brown (1998:14) are worth putting to the test: 'Finding out how to cook, or how to work with others is something that comes with doing it, feeling your way along. And the more you master your craft, the more you know that the way is to keep finding out the way, not by just doing what you are already good at, but by going off into the darkness'.

The concept of a sermon as an 'open work of art' offers a theoretical basis for the sermon as a dynamic-communicative event. Gerhard Marcel Martin and others (Garhammer \& Schöttler 1998) developed the concept of an 'open work of art' along the lines of ideas 
suggested by Umberto Eco. In their view, preaching should stage a biblical text rhetorically and within the context of a church service in such a way, that the congregation is able to apply it to its own views and experiences. This is called the 'aesthetics of reception' (cf. Nicol 2002:186-187). The view of the sermon as an open work of art was developed chiefly within the context of the New Homiletic.

According to Eugene Lowry (1997:15-28) the nature of the New Homiletic is the concept of the sermon as 'an ordered form of moving time.' This is diametrically opposed to the three-point static sermons that move forward from one point to the next. The traditional form of propositional preaching is replaced in the New Homiletic by representational preaching. Hence, preaching is transformed from a 'delivered message' to 'a creative event' (Eslinger 1987:13 et. seq.). The term, 'New Homiletic', which has been in use since 1987, marks a radical change from the 'old rationalistic paradigm' to the concept of preaching as a creative event (Childers 1998:37). Mike Graves uses the example of music to prove how absurd the old concept of preaching now seems to be, in light of the new one. "No musician", he says, "would give a concert consisting of a lecture instead of music". The New Homiletic aims to provide music and not a lecture on music. This approach no longer follows 'the method of distillation' according to which, life is reduced to a number of themes and statements. Sermons are now geared towards real life. Preaching performs life, life is movement, and preaching, therefore, should be 'plotted mobility'. In this way, sermons about reconciliation become part of life.

Martin Nicol (2002:188) links the idea of 'plotted mobility' with the idea of an open work of art. This gives rise to the concept of aesthetic homiletics. Preaching is connected to other forms of art, especially the performing arts. Art creates its own reality and in this respect it is comparable with the world of symbols. The theatre is an example of the performing arts. In oriental culture, the theatre had its origin in the mystery cult.

The Shakespearean producer, Peter Brook, defines his category of the 'holy theatre' as the form in which the invisible becomes visible. This also happens in the sermon: God's dealings with creation are visibly and creatively revealed. In the theatre of life, the focus is on God's relationship with people. The elements of this relationship 
include love, alienation, struggle, pain, reconciliation and expectation, while the 'stage' is creation. Creation suffers in the wake of human pain and destruction. Both the theatre and creation have a referred, rather than an inherent meaning. They both refer to what they proclaim.

The actor should not be concerned with concealment, but rather, with revelation (Max Reinhardt). The same applies to the sermon in which, the story and the deeds of God and man are revealed. The spectator identifies with a play, 'lives' in the world of the play and becomes part of it. He/she feels with the actors. A similar level of identification should take place in the sermon. The listener should allow him/herself to be persuaded by the sermon to place him/herself on God's side. The sermon should be so convincing, that it plays on the listener's faith. The 'theatre' is largely concerned with self-observation, self-knowledge, a meeting with self (Ulrich 1999:78). There are also moments of tension, conflict, uncertainty, anxiety, and joy (cf Ulrich 1999:78). All these elements should also be present in the sermon. As in the theatre, preaching should contain action, communication, progression, authenticity and dialogue.

The subject of tragedy is the relationship between the gods and mankind. Man's suffering, due to his complex relationship with the gods is revealed. Aristotle stated that the drama is not only intended for the eyes and ears of men, but that tragedy should evoke fear and sympathy, and therefore bring about a catharsis (Ulrich 1999:74; cf. also Ricoeur 1992:464-478). Tragedy arouses feelings of misery and uncertainty and allows people to shed some cathartic tears.

In Sophocles' play Antigone, Creon came to understand, after several painful experiences, that personal passions, which cannot be mastered, might cause peril for the city ([Sophocles] 2004:1-56). He confronts Antigone with this conviction, but she defends the equally valid rights of the individual. She dies and, crushed by his guilt, Creon desires 'never to see morning again'. This play inspired Hegel to arrive at his masterly meditation on what constitutes a tragedy: two antagonists, each tied to a truth that is partial and relative, but justified, confront each other. They are each prepared to sacrifice their lives for their own truth, but they can only triumph by the complete destruction of their opponent. They are both right and guilty. The great tragic characters have the honour of being guilty, says Hegel, and only deep- 
seated guilt can make a future reconciliation possible (Kundera 2003:78-79).

The Greeks attended a performance of Sophocles' Antigone every year, knowing full well what would happen to Antigone and Creon. They returned, because their participation as an audience in the tragedy of Antigone, threw light on the tragedy of their own lives, enabling them to work through it and achieve reconciliation.

In classical tragedy there are five acts: first act - exposition; second act - complication; third act - turning point; fourth act declining action and fifth act - denouement. The liturgy should contain something of the classical tragedy.

The regular churchgoer knows what will take place in the sermon. But he/she returns in the hope of being able to participate in the reenactment of the tragedy of his/her own existence, within the context of the tension between immanence and transcendence. The churchgoer knows that the homiletician will be able to provide a hermeneutic exposition of a text that is more or less successful, whether it is a synchronic or a diachronic exposition, or even a combination of the two. There remains, however, one expectation: the sermon should provide the lens through which the homiletician looks at life.

$\mathrm{He} /$ she is also aware that certain rituals will take place and is secretly hoping to be able to rediscover the tragedy of his/her own life in the sermon, not only cognitively, but also in an affective and participatory sense. This drew the Greeks to Antigone - the most sublime masterpiece of the ancient world (495-406 BCE) and this is what attracts the churchgoer to the sermon. Through the movements of the sermon he/she wants to achieve catharsis. The churchgoer wants to reach his/her deepest emotions and he/she wants to be confronted with his/her rights and their effect on other people. In the sermon, the clarification, i.e. the working through and purification of moral conflict should take place, allowing the churchgoer to take life head-on, with all its obstacles.

Comedy is one of the principal literary forms, although it is not the only one, in which comic elements are expressed (Conradie 1992:224-227). Comedy is intended to evoke a sense of freedom and happiness. The comic moments in the liturgy and the sermon could 
serve to unmask the vanity and stupidity of people. In the liturgy and the sermon the comic dimension can help to relieve the deadly earnestness of life through humour. People have to learn that they can laugh at their own helplessness and arrogance.

The sermon is not merely the performance of a tragedy and the solution of moral conflict. Amongst other things, it is a comedy. Comedy contains moments of happiness and so, the joyous aspect of the gospel must be heard in the sermon. The gospel is good news even for sinners, as it aims to make people happy. Comedia (cf. Dante's Divina Comedia) points to a happy ending, and the divine service too, ends on a happy note: the congregation stands and receives God's blessing to take with them. A life of reconciliation means a life of joy.

The distinction that Ricoeur makes between monuments and memorials can play a meaningful role in the sermon - as a reminder and a means of participation in God's drama (Ricoeur 1986; Jansen 2002:135-137, 324). Memorials keep the memory of the victims alive, whereas monuments honour the perpetrators as heroes. Monuments that are dedicated to the victims often represent history in a one-sided manner ('à nos enfants, morts pour la patrie'), whereas memorials keep questions, complaints and anxieties alive (Ricoeur 1986; Dosse 1997; Jansen 2002:135-137, 324). When speaking about God, (e.g. with reference to the Cross, or the Communion), the metaphor of the monument must be avoided (Jansen 2002:324). The sermon should not be about weaving commemorative wreaths from biblical stories or the recent past. It is important, however, for the sermon to commemorate the crucifixion as an act of reconciliation. Through the remembrance of the crucified Christ, we become one with him and experience his act of reconciliation.

\section{A FOCUS ON PARTICULAR BEARERS OF RECON- CILIATION}

This contribution focuses on two semantic fields of reconciliation - the expectations according to James and the reparation of relationships following a split.

The following, about the Epistle of James, is supported by the exegetical and theological insights of Steyn (2005). The Epistle of James, in particular, concentrates on the requirements for a sound and 
healthy relationship on a horizontal level. The acknowledgement and confession of a repaired relationship between God and humanity, is like an empty frame on a building site. It is not only the vertical pillars that are necessary, but also the horizontal beams. Building rows of stones horizontally next to each other, layer upon layer ensures a structure that will protect one from the onslaught of the elements. James focuses on this dimension. He becomes uncomfortably practical in describing these horizontal relationships.

From a socio-historical point of view, James explores the primary relationship between the rich and the poor, both in the congregation (Ja 1:9-11 and 2:1-13) and on the farms (Ja 5:1-6). The relationship between these social classes was tense. People were judgmental and biased (Ja 2:1) which was deemed sinful and an act of breaking the law

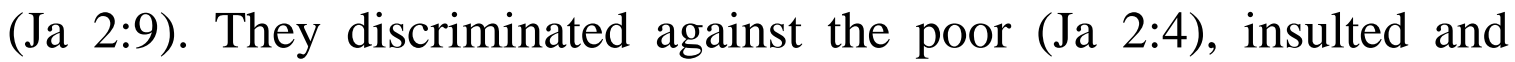
exploited them and took them to court (Ja 2:6). The rich hoarded wealth (Ja 5:3) and failed to pay wages to the workers (Ja 5:4). They lived in luxury and self-indulgence (Ja 5:5). This created a division between these social groups. The result was that the rich and the poor believers did not act according to what they said they believed. Faith became empty and not an act of mutual love.

Therefore, for James, the expectation of a reconciled relationship between a believer and God means that faith without work does not exist (Ja 2:14-26). In fact, action is the visible proof of faith (Ja 2:18). There can be no talk of faith without action. Affluent believers cannot merely talk to someone in need, without also addressing the needs of such a person (Ja 2:16). Meanwhile, the caution expressed against the taming of the tongue (Ja 3;1-12; 4:11-12), against bitter envy and selfish ambition (Ja 3:14), against quarrels because people wanted something that they could not get (Ja 4:1-2), the call to be patient in suffering and to persevere (Ja 5:7-11) was probably aimed at poorer believers.

It becomes clear from the section that deals with the taming of the tongue (Ja 3:1-12), that communication between people is a real expectation for James, as well as communication with God (e.g. in the sections that deal with prayer Ja $4: 3 ; 5: 13-18)$. In fact, the vice lists in Ja 3:1-18 point to actions that corrupt love relationships between Christians who are in a vertical relationship of reconciliation. The 
reality of a restored relationship with God will take shape in practice and the renewed status will be evident in the actions. Communication is a vital expectation of Christians who have been reconciled with God through Jesus Christ.

When bearing in mind the context and nature of this epistle, it seems to end on a surprising note: Christians should take responsibility for on another and actively bring back those who have drifted away. In doing this, they will save their fellows from death and will assist in the forgiveness of their sins (Ja 5:19-20). This highlights the mediating role that Christians can play in the process of reconciliation.

Poverty is a complex, contextual problem. A universal model, simplistically imposed on a country would fail to come to grips with the problem. A lifestyle modelled on Western culture runs the risk of interpreting poverty primarily from a Western perspective. To avoid this, poverty must be tackled as a complex cultural and social reality. Poverty cannot be seen simply as a matter of cause and effect: human existence is too complex (Vos 2003:231-242).

It is clear, that the world's economic system is no longer serving humankind, but causing poverty and destroying the biosphere. The increase in the growth of the gross domestic product (GDP) in African countries since the beginning of the nineties does not compare with the creation of permanent, safe job opportunities for both skilled and unskilled workers (Le Pere 2000:10). The number of qualified people who are unable to obtain employment is increasing annually. In the black communities, people speak of “jobless graduates”.

Furthermore, the growth in the GDP has outstripped the growth in democracy and is probably contributing to the degradation of the environment. The wealthy members of society skim off most of the benefits that accrue from this growth (Le Pere 2000:10).

In general, the burden of poverty is most severe amongst women and matriarchal households. Moreover, the poverty of women has direct implications for poverty in African families. It is estimated that about a third of African households are matriarchal. It is further estimated, that the proportion of women living in absolute poverty has risen by $50 \%$ over the past twenty years, while the figure is at $30 \%$ for men over the same period. 
From the summary of the Epistle of James, it is evident that reconciliation deeply affects the relationship between rich and poor. The rich cannot ignore the poor after reconciliation has been reached. Reconciliation intensifies human beings' sense of social responsibility and social consciousness. Poverty cannot be ignored. Reconciliation asks of the rich, "What are you doing for the poor? What are you doing to relieve poverty? What acts of love are you bestowing on the poor?" The poor should not long for that which cannot be realised, as this will only lead to quarrels. The community of faith must offer the poor a home; they may not marginalize or reject the poor. Instead they are called upon to care for them. The love of God must be shown to the poor.

The Son has taught us that it is more blessed to give than to receive (Acts 20:35). In the proverb used by Paul, the emphasis is on the members of the community, who support one another (Theissen 2000:136). We owe one another, especially the poor, care and love in the service of the Christian family. Our honour lies in fulfilling this duty. In God's family, those in need, have a higher status than those who provide assistance do (Mt 25:44).

Preachers need to show solidarity with the congregation and the community regarding the issue of poverty and this requires acquiring existential knowledge of the situation.

Pieterse (2001:86-90) provides an excellent summary about preaching in a context of poverty, which I support. Pastoral closeness to people is important. One has to listen to people's stories and their views about life, God, the church, the government and others. By being with people in their distress, taking their side, by supporting them pastorally and showing them God's love, one starts gaining their trust. The preacher has to see life, religion, God, the government and others through the eyes of the people - this is how existential knowledge of their context and of them as human beings is acquired.

Preachers have to glean ideas and acquire contributions about the meaning of the text from the congregation, (who are the poor), when preparing a sermon. That is part of the first phase of the hermeneutic cycle. They will have to sit down with groups of parishioners and ask them what the biblical texts mean to them. What feelings does it evoke 
for them? How have they experienced that text in the past? How was it explained to them? What comfort, hope inspiration or negativity does it impart to them? This dialogue will give the preacher an idea of the effect that the text will have in the sermon and how pitch the message. Moreover, by expressing their own understanding of the text, the poor appropriate the message of the text. Thus, the sermon starts to influence their lives.

It should be evident by now, that when we approach biblical texts with a view to interpreting them for preaching purposes, we should do so from the perspective of the poor, i.e. terms of their need for justice and righteousness.

All ideologies that weaken and jeopardise the position of the poor have to be identified in prophetic preaching. Abuse of power, no matter by whom, must be pointed out. Hence, hermeneutics always functions in an ideologically critical way. Such prophetically critical hermeneutics allows us to interpret the message of the text creatively, so that our preaching to the poor is liberating.

Prophetic sermons must be delivered in such a way, that the listeners are able to respond obediently and transform their situation positively and through action. To this end, the process of understanding and translation should be directed in a creative way. Prophetic sermons should be preached in a prophetic style and should communicate in the language, terminology and spirit of the times as exists in a specific context.

The Greek noun, katallage, and the corresponding verbs in the Corpus Paulinum are highlighted in this contribution. The semantic domain of this Greek word is that of re-establishing friendly, interpersonal relations after these have been disrupted or broken. The components of this series of meanings involve the disruption of friendly relations because of presumed, or real provocation; overt behaviour designed to remove hostility, and restoration of original friendly relations ('to reconcile, to make things right with one another, reconciliation') (Louw and Nida 1998:502).

In 1 Corinthians 7:11 reconciliation revolves around a broken marriage. Should a woman get divorced, she must stay unmarried, or she must reconcile (verb) with her husband. In Romans 5:10; 2 
Corinthians 5:18, 19, 20 the verb is used in context of the relationship between God-man. The pronoun is used in Romans 5:11; 11, 15; 2 Corinthians 5:18-2019 and the imagery is obvious. It presupposes a state of estrangement or hostility between God and mankind (cf Rm 5:10; Col 1:21; Eph 2:16). The idea that a death can bring about reconciliation may itself evoke the idea of martyr theology (as implied also in Rm 5:7) (Dunn 1998:229).

There are several notable features in 2 Corinthians 5:18-21. (a) One is the strong insistence that reconciliation is between God and the world. It is the fundamental Creator/creature relationship, which is being restored here. Christ is the medium of the reconciliation, not the one who is reconciled. (b) Another equally strong insistence, is that God was involved in the act of reconciliation - 'through Christ' (v.18), 'in Christ' (v.19). The emphasis is the same as in Romans 3.25 and 2 Corinthians 5.21. The imagery is not that of God as an angry opponent having to be cajoled or entreated, but of God, the injured partner, actively seeking reconciliation. (c) Equally striking is the correlated or alternative metaphor - 'not counting their transgressions against them'. The image of forgiving or choosing to ignore active hostility can be as effective as that of sacrifice of sins. (d) Not least, is the confirmation that the message of reconciliation, which is focused on the Cross (1 Cor 5.21) is at the heart of the gospel. If Christ is the representative of God in effecting reconciliation ('God was in Christ'), then the apostles are the representatives of God in proclaiming it ("God makes his appeal through us”) (Dunn 1998:229).

We should note that subsequently, in Colossians 1.20, the thought of God reconciling the world through Christ is elaborated - 'through him to reconcile all things to him, making peace through the blood of his cross (through him), whether the things on the earth or the things in the heavens'. The reconciliation of individuals with God (1 Col. 22), and particularly the reconciliation of Jew and Gentile (Eph. 2.16), are stages in a greater cosmic plan. That is presumably why the Church in both these epistles can (or should) function as the locus of (and pattern for!) the reconciled world (Col. 1.18; Eph. 1.22-23) (Dunn 1998:230).

Reconciliation is an act of God through Christ. Christ is the one who brings about reparation (1 Cor 5:18; Rm 5:11). He is the Rectifier, Reconciler, Mediator and Bridge-builder. The Holy Spirit effects the 
reconciliation. Reconciliation is proof of God's Love to sinners (Rm 5:8), weaklings ( $\mathrm{Rm}$ 5:8) and enemies (Rm 5:9). Man can only accept the act of justification through faith ( $\mathrm{Rm} 5: 1)$. He/she can only receive

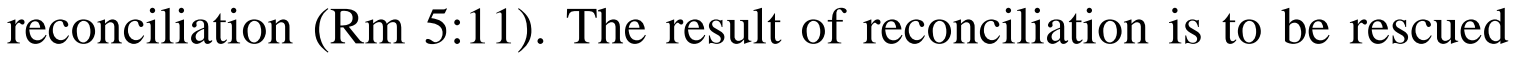
from judgement (Rm 5:10) and to experience joy ( $\mathrm{Rm}$ 5:11).

The reconciled are touched by the act of God's reconciliation through the Holy Ghost and accepted into the diakonia of reconciliation (2 Cor 5:18), the service of justice (2 Cor 3:9) and the service of the Holy Ghost (2 Cor 3:6, 8). The preacher becomes a messenger of reconciliation. "We beg you, in the Name of Christ, accept the reconciliation with God, which he has brought about!” (2 Cor 5:20). This means they should enter into the reconciled relationship with God by accepting his peace and grace as a gift (Joubert 2005).

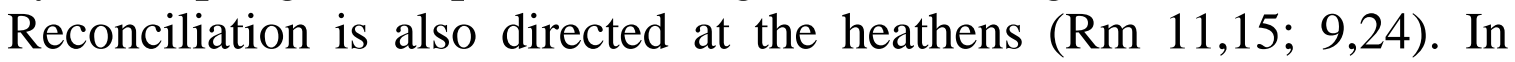
Colossians 1:15-20, the cosmic extent of Christ's salvation is evident. The reconciliation with God, results in the reconciliation with man, who has, thus far, lived with animosity (Eph 2:16). The Church is reflected as a place of salvation where reconciliation is received. Salvation is given and created through the sermon. This gift is accepted through faith.

Shattered relationships can be experienced on different levels and even the most intimate of relationships can experience a breakdown. For this reason, a breakdown in a marriage is more painful. In my poem, Marriage, the breakdown of the relationship is evident:

A year or five after the wedding

a mistress whispers words into the man's ear.

his wife is numb with grief, with nothing, he denies everything.

The man searches for his wife with an SOS from his heart in places where the twilight lies like a tired dog; on the plains of his imagination, in the cool shelter of a maitresse's corridors. 
A cold war holds no place for God and his decree.

husband and wife drag one another

into the dark ditches

where wounds take bloodied breaths.

Let us try again.

Life has many precipices,

with love being the deepest.

A truce and reconciliation,

a light, awkward touch,

oysters and caviar, Mozart's

Le nozze di Figaro,

the rhythm of sex and charm.

They wait for the future and the gods

in a land where miracles are few

and the hours are colourless without sound.

They dance and turn to one another

for the kiss of death in the quiet night.

How can a broken marriage be healed? Through reconciliation. The rift between God and man can only be mended through reconciliation. Christ is the Reconciler, the Mediator, the Rectifier and the Bridgebuilder. On a daily basis, the Holy Ghost reminds the hus-band and wife who are in a relationship with one another and with God, about the reparation that Christ has brought about.

\section{RECONCILIATION IS OPEN-ENDED}

Reconciliation opens doors that lead into the future. Our relationships and deeds must affirm that we have been touched and changed by the reconciliation of the Reconciler. Reconciliation enables us to make a difference in others' lives. This is possible because God's reconciliation through Christ has made a difference between Him and us.

\section{Consulted literature}

Brown, E E 1997. Tomato Blessings and Radish Teachings. New York: Riverhead Books. 
Childers, J Performing the Word. Preaching as Theatre. Nashville: Abingdon Press.

Conradi, P J 1992. 'Komedie', in: Cloete, T T (red) Literêre terme en teorieë. Pretoria: HAUM Literêr, 195-208.

Dosse, F. 1997. Paul Ricoeur. Les sens d'une vie. Paris: Dècouverte.

Dunn, J D G 1998. The Theology of Paul the Apostle. Grand Rapids, Michigan: Eerdmans.

Eslinger, R 1987. A New Hearing. Living Options in Homiletical Method. Nashville: Abingdon Press.

Garhammer, E 1998. 'Handlanger des katholischen Milieus?' - Zur Rolle der Literatur in der Verkündigung, in: Mödl, L, Schöttler, H-G \& Ulrich, G (Hrsg.). Das Evangelium ist eine Kraft Gottes. Die Predigt in den kulturellen Räumen der Gesellschaft, 60-72. München: Don Bosco.

Garhammer, E \& Schöttler, H-G (eds) 1998. Predigt als offenes Kunstwerk. Homiletik und Rezeptionsästhetik. München: Chr. Beck.

Immink, G \& Stark C (eds) 2002. Preaching: Creating Perspective (Studia Homiletica 4). Utrecht: Societas Homiletica.

Jansen, M M 2002. Talen naar God. Wegwijzers by Paul Ricoeur. Nijmegen.

Kundera, M 2003. Translation from Le Monde Diplomatique. Insig, Augustus 2003, 78-79

Le Pere, G 2000. Beeld (21 November 2000), 10.

Louw, J P \& Nida, E A (eds) 1988. Greek-English Lexicon of the New Testament based on semantic domains. Volume 1: Introduction \& Domains. New York: United Bible Societies.

Lowry, E 1997. The Sermon. Dancing the Edge of Mystery. Nashville: Abingdon.

Nicol, M., 2002. The art of preaching versus the doctrine of God? The role dogmatics plays in preaching, in: Immink, G \& Stark, C (eds). Preaching: Creating Perspective (Studia Homiletica 4), Utrecht: Societas Homiletica, 184195.

Pieterse, H J C 2001. Preaching in a context of poverty. Pretoria: Unisa Press.

Ricoeur, P 1986. Du texte à l'action. Essais d'herméneutique II. Paris: Seuil.

-, 1992. Lectures. La Contrée des Philosophes. Paris: Seuil.

[Sophocles] 2004. The Burial at Thebes. Sophocles' Antigone. Translated by Seamus Heany. London.

Steyn, G J 2005. A framework for understanding reconciliation in the so-called General Epistles in: Van der Watt, J G, Human, D J \& Steyn, G J (eds) 
Friendship and love where there were none. Biblical perspectives on reconciliation. Pretoria: ISWEN/Lux Verbi.

Theissen, G 2000. Die Religion der ersten Christen. Eine Theorie des Urchristentums. Gütersloh: Gütersloher Verlagshaus.

Ulrich, G 1999. Theater und Gottesdienst - Eine gemeinsame Wurzel, in: Mödl, L. Schötler, H-G \& Ulrich, G (Hrgs). Das Evangelium ist eine Kraft Gottes. Die Predigt in den kulturellen Räumen der Gesellschaft. München: Don Bosco, 7380.

Vos, C J A 2003. God's people: Reflections on Ecclesiology and the Poor, in: Couture, P D \& Miller-McLemore, B J (eds). Poverty, Suffering and HIVAIDS. International Practical Theological Perspectives. Cardiff: Cardiff Academic Press, 231-245. 